\section{Estimating changes in soil organic carbon storage due to land use changes using a modified calculation method}

\author{
Yuwu Li ${ }^{(1-4)}$, Yujie Xia ${ }^{(2)}$, Yanbao Lei ${ }^{(3)}$, Yun Deng ${ }^{(1)}$, Hui Chen ${ }^{(1)}$, Liqing \\ Sha ${ }^{(1)}$, Min Cao ${ }^{(1)}$, Xiaobao Deng ${ }^{(1)}$
}

Carbon sources and sinks have been widely scrutinized over the last ten years as a result of the Kyoto Protocol. In this paper we added a new concept (standardized reference depth, $D_{S R}$ ) to the current calculation method in order to assess and compare the soil organic carbon (SOC) storage changes due to three major land use changes with a certain historical relationship (from primary rain forest to fallow land to natural secondary forest and finally to rubber plantations - Hevea brasiliensis) in a northern tropical ecosystem in southwest China. Over $\mathbf{3 0}$ years, the soil organic carbon storage did not decrease significantly with a land use change from primary rain forest to fallow land (approximately $10.3 \%$ ). However, it did increase significantly (approximately $49.3 \%$ ) due to conversions to natural secondary forest and rubber plantations (approximately 41.6\%). In this region, the soil carbon sequestration at rubber plantations is similar to that of natural secondary forests. Compared with the modified method, the current method overestimated carbon storage on fallow land by $\mathbf{8 . 8 \%}$ more than the actual storage (calculated reference depth of $13.9 \mathrm{~cm}, D_{\mathrm{r}}-D_{\mathrm{SR}}=$ 13.9 , without the reference depth standardization process), overestimated carbon storage at rubber plantations by $3.6 \%$ (calculated reference depth of $4.9 \mathrm{~cm})$, and underestimated the natural secondary forest carbon storage by $6.4 \%$ (calculated reference depth of $9.7 \mathrm{~cm}$ ). Thus, the modified process using the standardized reference depth for the current method is necessary for the evolution and comparison of soil carbon or other nutrient storage changes.

Keywords: Soil Organic Carbon Storage, Land Use Change, Modified Calculation Method, Rubber Plantation, Tropical Forest, Kyoto Protocol

\section{Introduction \\ As a result of the Kyoto Protocol, which was established at the United Nations Framework Convention on Climate Change in 1997, all of the signatory countries have their own periodic Kyoto carbon trading quotas and goals for reducing $\mathrm{CO}_{2}$ emissions levels based on the global periodic average quota and their own country's carbon stora- ge. The identification of plant-soil ecosys- tems that promote carbon sequestration is}

therefore of considerable importance (Wilson \& Puri 2001). The quantity and rate of accumulation of carbon in different ecosystems have been widely studied over the last ten years, and the requirement for accuracy in estimating soil carbon storage is increasing. The practice involves the equity and reasonability of each country's periodic Kyoto carbon trading quotas and goals for reducing $\mathrm{CO}_{2}$ emissions levels in the future.

There are three main reservoirs that regu-

(1) Key Laboratory of Tropical Forest Ecology, Xishuangbanna Tropical Botanical Garden, Chinese Academy of Sciences, Yunnan 666303 (China); (2) Kunming Institute of Zoology, Chinese Academy of Sciences, Yunnan 650223 (China); (3) Institute of Mountain Hazards and Environment, Chinese Academy of Sciences,, Sichuan 610041 (China); (4) Key Laboratory of Rubber Biology and Genetic Resource Utilization, Ministry of Agriculture, Hainan 571731 (China)

(a) Xiaobao Deng (lyw@xtbg.org.cn)

Received: Oct 14, 2013 - Accepted: Apr 23, 2014

Citation: Li Y, Xia Y, Lei Y, Deng Y, Chen H, Sha L, Cao M, Deng X, 2015. Estimating changes in soil organic carbon storage due to land use changes using a modified calculation method. iForest 8: 45-52 [online 2014-06-17] URL: http://www.sisef.it/iforest/contents/?id= ifor1151-007

Communicated by: Gianfranco Minotta

late the global carbon cycle. From 1750 to 2011, the cumulative anthropogenic $\mathrm{CO}_{2}$ emissions were about $2035 \mathrm{Gt}$ from fossil fuel combustion, cement production, and land use change. Of these cumulative anthropogenic $\mathrm{CO}_{2}$ emissions, $43.24 \%$ have accumulated in the atmosphere, $28.83 \%$ have accumulated in natural terrestrial ecosystems and $27.93 \%$ have been taken up by the ocean (Stocker et al. 2013).

Although the natural terrestrial ecosystem is not the largest accumulation reservoir, it can be changed markedly by the direct impact of human activities and is potentially more labile than other reservoirs in the shortterm (Batjes 1996). It is generally recognized that soils represent the largest proportion of the terrestrial carbon reservoir (approximately $1500 \mathrm{Gt}$ - Batjes 1996, Batjes \& Sombroek 1997), and soils contain more organic carbon than the atmosphere and biosphere combined (Meersmans et al. 2008). The carbon balance of soil inputs and outputs has a critical influence on the concentration of atmospheric $\mathrm{CO}_{2}$; the release of greenhouse gases from the soil could enhance the "greenhouse effect" and, possibly, cause global climatic anomalies, which, in turn, could cause a series of ecological problems and influence the health of ecosystems that support human civilization (Ellert \& Bettany 1995, John et al. 2005).

Land use change is an important factor that controls soil organic carbon storage because it affects the amount, location and composition of the litterfall input, decomposition and processes of organic matter stabilization (John et al. 2005). Land use changes, therefore, can change the total amount of soil organic carbon that is stabilized as well as the soil's environmental factors, such as temperature, moisture, and the accessibility of energy sources for soil organisms (Ellert \& Bettany 1995). Land use change, such as deforestation, caused approximately one fourth of the anthropogenic $\mathrm{CO}_{2}$ emissions from 1985-2005 (Barnett et al. 2005). Changes in land use and vegetation type also cause soil carbon depletion by influencing soil respiration and carbon fluxes in the soil (Post \& Kwon 2000). The patterns and dynamics of ecosystem carbon storage after land use changes are of particular interest in estimating the gains and losses of soil carbon at a regional scale (Wilson \& Puri 2001, Zhang et al. 2007a).

Many studies have made great contributions to establishing a more accurate calculation method for soil organic carbon storage (e.g., Kern 1994, Batjes 2000, Schumacher 2002, Sleutel et al. 2003, Lettens et al. 2004). Usually, soil organic carbon storage is calculated by multiplying the soil organic carbon content, soil bulk density and soil thickness (Kern 1994, Batjes 2000, Lettens 
et al. 2004, Meersmans et al. 2008). An example of this calculation approach was previously described by Meersmans et al. (2008).

However, in our opinion, such current calculation method is still insufficient for assessing soil organic carbon storage correctly, because it still lacks the strict sense of comparability among different land uses, especially when different land uses have certain historical relationships. The current method lacks a simple but indispensable parameter, the standard reference depth $\left(D_{\mathrm{SR}}\right)$. A depth of $100 \mathrm{~cm}$ was selected as the most common reference depth $\left(D_{\mathrm{r}}\right)$ in order to facilitate comparisons with international literature in related studies (Meersmans et al. 2008). $D_{\mathrm{SR}}$ is the true comparative depth of $D_{\mathrm{r}}$ for land use changes that are due to disturbance or other reasons. The specific standardization process to convert $D_{\mathrm{r}}$ to $D_{\mathrm{SR}}$ is described below.

Here, we use an extreme example to explain the great scientific significance and the necessity of reference depth standardization. On a common farmland, if we trample the surface continuously for 10 hours, soil bulk density would increase, and the original thickness of the farmland soil would decline to less than $100 \mathrm{~cm}($ e.g., $80 \mathrm{~cm})$. Using the current method to calculate and compare the soil carbon storage without the reference depth standardization step, we will come to the interesting conclusion that trampling can increase the soil carbon storage. This conclusion is obviously wrong, however, because additional carbon storage was added with the $20 \mathrm{~cm}$ of soil depth in addition to the original $100 \mathrm{~cm}$ thickness. In fact, the amount of soil organic carbon did not increase or decrease after trampling the soil. To resolve this discrepancy, the equivalent mass basis was used for calculating soil carbon storage to compare different land use types (e.g., Veldkamp 1994, Ellert \& Bettany 1995,
Yang \& Wander 1999). The standardization of the new reference depth is necessary for more accurate calculations if we sample each of the soil layers for bulk density, rather than some of the soil layers only.

Economic tree plantations have been a significant element of land-use conversions (Liao et al. 2012). Globally, the total plantation area was approximately $1.39 \times 10^{8}$ ha in 2005 and is still expanding rapidly at an approximate annual rate of 2\% (FAO 2005, Van Dijk \& Keenan 2007). Rubber trees (one of the most economic tree species, primarily originating from Brazil) have been planted in many countries over the past 100 years. The total rubber plantation area globally was approximately $1.01 \times 10^{7}$ ha in 2010 and $91 \%$ of it was located in south and southeast Asia (approximately $9.16 \times 10^{6}$ ha FAO 2010). Rubber plantations have expanded rapidly over the past 20 years in tropical Asia and their impacts on regional carbon cycling have drawn worldwide attention. The rate of plantation expansion is similar in tropical China (at the northern margin of tropical SE Asia). With the rapid economic development and the increased demand for natural resources, such as rubber latex, 139576 ha of natural forest were cleared between 1976 and 2003 in Xishuangbanna. The area of natural forest decreased from $70 \%$ in 1976 to $50 \%$ in 2003 , largely due to the expansion of rubber plantations ( $\mathrm{Li}$ et al. 2007). The total rubber plantation area was approximately $4.0 \times 10^{5}$ ha in Xishuangbanna (Xu et al. 2014). However, even with the large expansion in the area of rubber plantations in Xishuangbanna, and despite of the world's first crown of the rubber yield production (Zhou \& Liu 2004), the status of soils at rubber plantations as either carbon "sinks" or "sources" is currently unknown.

This study focuses on changes in soil organic carbon storage during primary land use changes in the northern tropical ecosystem

\section{Fig. 1 - Bagnouls-}

Gaussen ombrothermic diagram of

Xishuangbanna (1980-2008). When monthly precipitation $\mathrm{P}>100 \mathrm{~mm}, \mathrm{P}$ is denoted as $\mathrm{P}^{\prime}$ in the diagram, and $\mathrm{P}^{\prime}=100+$ $(\mathrm{P}-100) / 10$.

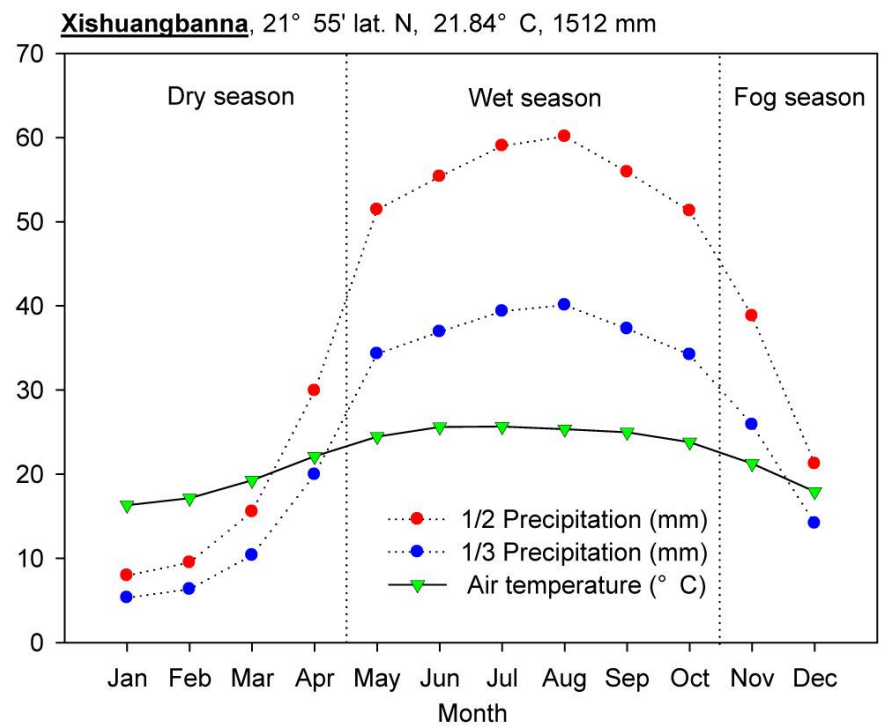

(primary rain forest, fallow land, natural secondary forest and monoculture rubber plantation). The main objective was to quantify the changes in soil organic carbon storage using a modified calculation method by including a new concept, the standardized reference depth $\left(D_{\mathrm{SR}}\right)$, in the calculation for the conversion of primary rain forest to other land uses under heavy human activity in Xishuangbanna. It was expected that the modified method would be useful for accurately estimating soil organic carbon or nutrient storage in terrestrial ecosystems that are experiencing changes in land management.

\section{Materials and methods}

\section{Study site}

The study was conducted in the Xishuangbanna National Tropical Rain Forest Reserve $\left(21^{\circ} 09^{\prime}-22^{\circ} 33^{\prime} \mathrm{N}, 99^{\circ} 58^{\prime}-101^{\circ} 34^{\prime} \mathrm{E}\right)$ in southwestern China, at the northern edge of tropical SE Asia. Located in the East Asian monsoon region, Xishuangbanna is dominated by warm, wet air masses from the Indian Ocean in the summer and continental air masses from the subtropical regions in the winter, resulting in a highly seasonal environment (Cao et al. 1996, Liu et al. 2005). Mean annual rainfall was $1512 \mathrm{~mm}$ (19802008) and mean monthly temperature was $21.7^{\circ} \mathrm{C}(1980-2008$ - weather data from the Xishuangbanna Station for Tropical Rain Forest Ecosystem Studies). The climatic ombrothermic diagram is illustrated in Fig. 1.

The experimental design consisted of four land use types, including primary rain forest (PRF), fallow land (FL), natural secondary forest (NSF), and monoculture rubber plantation (RP) with three replicate profiles at each site. All of the sites were located on yellow latosol, which developed from purple sandstone at elevations of between 560 and $750 \mathrm{~m}$. The map of study sites was previously published by $\mathrm{Li}$ et al. (2013). The main vegetation characteristics, management techniques and the historical relationships among them are described in Tab. 1 (Li et al. 2013).

\section{Soil sampling and analysis}

Soil samples were collected in November 2010 from three profiles after the litterfall and grass layer were carefully removed at three slope positions (up slope, middle slope, and down slope) for each type of site. The cores were divided into eight depth intervals: $0-10,10-20,20-30,30-40,40-60$, $60-80,80-100$ and $100-120 \mathrm{~cm}$. The soil bulk density was measured using the cutting ring method (Liu et al. 1996). After removing the visible plant debris, including roots and stones, soil samples were sieved $(2 \times 2$ $\mathrm{mm})$ and dried at room temperature $\left(\sim 20^{\circ} \mathrm{C}\right)$ for approximately 2 weeks. The air-dried samples were stored at room temperature in 
Tab. 1 - Vegetation characteristics of the four study sites. (PRF): primary rain forest; (FL): fallow land; (NSF): natural secondary forest; (RP): rubber plantation. Study sites are the same as in Li et al. (2013).

\begin{tabular}{|c|c|c|c|c|}
\hline Characteristics & PRF & FL & NSF & $\mathbf{R P}$ \\
\hline Forest age (year) & $>200$ & $4 \sim 5$ & 30 & 30 \\
\hline Canopy height (m) & $35 \sim 40$ & $2 \sim 3$ & $10 \sim 12$ & $18 \sim 20$ \\
\hline Dominant species & $\begin{array}{l}\text { Pometia pinnata, } \\
\text { Terminalia myriocarpa, } \\
\text { Semecarpus reticulata }\end{array}$ & $\begin{array}{c}\text { Eupatorium doratum, } \\
\text { Digitaria ciliaris }\end{array}$ & $\begin{array}{l}\text { Litsea mollis, } \\
\text { Litsea umbellate, } \\
\text { Castanopsis indica }\end{array}$ & Hevea brasiliensis \\
\hline Litter-fall $\left(\mathrm{kg} \mathrm{ha}^{-1} \mathrm{yr}^{-1}\right)$ & 10.800 & 6.500 & 14.200 & 7.000 \\
\hline $\begin{array}{l}\text { Litter-fall decomposition } \\
\left(\mathrm{kg} \mathrm{ha}^{-1} \mathrm{yr}^{-1}\right)\end{array}$ & 8.800 & 5.900 & 13.400 & 2.100 \\
\hline Management & No & No & No & $\begin{array}{l}\text { Fertilization } 2 \text { times } \mathrm{yr}^{-1} \text {; Mixed fertilizer } \\
(\mathrm{N}, \mathrm{P}, \mathrm{K}) 180 \mathrm{~kg} \mathrm{ha}^{-1} \mathrm{yr}^{-1} \text {; } \\
\text { Weeding } 3 \sim 4{\text { times } \mathrm{yr}^{-1}}^{-1}\end{array}$ \\
\hline Annual harvest & No & No & No & Dry rubber latex $2600 \mathrm{~kg} \mathrm{ha}^{-1}$ \\
\hline Historical land use type & Unknown & PRF & FL & FL \\
\hline
\end{tabular}

an air-tight container for chemical analysis. The soil total organic carbon content was analyzed using the wet digestion method (Nelson \& Sommer 1975, Liu et al. 1996).

\section{Calculation of soil total organic carbon} storage

Data from different land uses are listed in Tab. 2. Two different methods were used to calculate the storage of soil organic carbon (SOC) using the same datasets for each land use type. We used the primary rain forest as reference land type since the other three types were all transformed from primary rain forest. The first method was the current method, described by Meersmans et al.
(2008). The second (modified) method is described below.

If we define $A$ as a soil sampling profile of the primary rain forest and $B$ as a soil sampling profile of one of the three land uses (fallow land, natural secondary forest or rubber plantation), then for an equal soil mass, the soil mass of $A$ with a reference depth $\left(D_{\mathrm{r}}\right.$ $=1 \mathrm{~m}$ of $n$ layers) is equal to the mass of $B$ with a standardized reference depth $\left(D_{\mathrm{SR}}\right.$ of $k$ layers). Hence, we can easily obtain the following inequality $(I-$ eqn. 1$)$ :

$$
\sum_{i=1}^{k-1} \rho_{B i} \cdot T_{B i} \leq \sum_{i=1}^{n} \rho_{A i} \cdot T_{A i} \leq \sum_{i=1}^{k} \rho_{B i} \cdot T_{B i}
$$

where $\rho_{\mathrm{i}}$ is the soil bulk density of the $i$-th
Tab. 2 - Soil bulk density and soil organic carbon content in the different land uses.

\begin{tabular}{|c|c|c|c|c|c|c|c|c|c|c|}
\hline \multirow{2}{*}{$\begin{array}{l}\text { Repli- } \\
\text { cate } \\
\text { profiles }\end{array}$} & \multirow{2}{*}{$\begin{array}{c}\text { Soil } \\
\text { depth } \\
(\mathrm{cm})\end{array}$} & \multirow[t]{2}{*}{$\begin{array}{c}\text { Layer } \\
\text { No. }\end{array}$} & \multicolumn{4}{|c|}{$\begin{array}{l}\text { Soil bulk density } \\
\qquad\left(\mathrm{g} \mathrm{cm}^{-3}\right)\end{array}$} & \multicolumn{4}{|c|}{$\begin{array}{c}\text { Soil organic } \\
\text { carbon content } \\
\left(\mathrm{g} \mathrm{kg}^{-1}\right)\end{array}$} \\
\hline & & & PRF & FL & NSF & $\mathbf{R P}$ & PRF & FL & NSF & $\mathbf{R P}$ \\
\hline \multirow[t]{8}{*}{ No.1 } & $0-10$ & 1 & 1.18 & 1.36 & 1.25 & 1.38 & 38.22 & 22.78 & 28.53 & 30.2 \\
\hline & $10-20$ & 2 & 1.25 & 1.48 & 1.29 & 1.42 & 17.98 & 13.94 & 22.36 & 20.47 \\
\hline & $20-30$ & 3 & 1.4 & 1.59 & 1.32 & 1.48 & 11.09 & 10.66 & 20.07 & 12.96 \\
\hline & $30-40$ & 4 & 1.36 & 1.62 & 1.33 & 1.45 & - & - & - & - \\
\hline & $40-60$ & 5 & 1.34 & 1.69 & 1.34 & 1.51 & 9.91 & 7.06 & 13.88 & 11.21 \\
\hline & $60-80$ & 6 & 1.44 & 1.58 & 1.18 & 1.45 & 8.27 & 5.67 & 11.96 & 10.51 \\
\hline & $80-100$ & 7 & 1.47 & 1.64 & 1.23 & 1.47 & - & - & - & - \\
\hline & $100-120$ & 8 & 1.48 & 1.64 & 1.29 & 1.49 & - & - & - & - \\
\hline \multirow[t]{8}{*}{ No.2 } & $0-10$ & 1 & 1.05 & 1.26 & 1.12 & 1.38 & 28.37 & 29.58 & 46.92 & 37.22 \\
\hline & $10-20$ & 2 & 1.32 & 1.48 & 1.16 & 1.37 & 14.54 & 21.63 & 25.29 & 24.97 \\
\hline & $20-30$ & 3 & 1.33 & 1.48 & 1.17 & 1.39 & 8.93 & 11.9 & 18.96 & 20.38 \\
\hline & $30-40$ & 4 & 1.33 & 1.6 & 1.26 & 1.45 & - & - & - & - \\
\hline & $40-60$ & 5 & 1.45 & 1.62 & 1.22 & 1.45 & 8.84 & 5.71 & 13.27 & 12.53 \\
\hline & $60-80$ & 6 & 1.42 & 1.58 & 1.28 & 1.45 & 7.47 & 4.73 & 10.81 & 10.7 \\
\hline & $80-100$ & 7 & 1.48 & 1.69 & 1.25 & 1.39 & - & - & - & - \\
\hline & $100-120$ & 8 & 1.46 & 1.68 & 1.29 & 1.48 & - & - & - & - \\
\hline \multirow[t]{8}{*}{ No.3 } & $0-10$ & 1 & 1.1 & 1.34 & 0.91 & 1.42 & 27.12 & 19.91 & 51.45 & 27.28 \\
\hline & $10-20$ & 2 & 1.25 & 1.48 & 1.13 & 1.33 & 18.34 & 12.15 & 29.35 & 17.93 \\
\hline & $20-30$ & 3 & 1.29 & 1.41 & 1.11 & 1.36 & 14.1 & 11.6 & 22.04 & 22.47 \\
\hline & $30-40$ & 4 & 1.25 & 1.52 & 1.09 & 1.29 & - & - & - & - \\
\hline & $40-60$ & 5 & 1.3 & 1.5 & 1.23 & 1.35 & 9.14 & 9.42 & 17.45 & 18.81 \\
\hline & $60-80$ & 6 & 1.38 & 1.54 & 1.25 & 1.43 & 8.29 & 8.62 & 12.47 & 13.47 \\
\hline & $80-100$ & 7 & 1.45 & 1.54 & 1.25 & 1.43 & - & - & - & - \\
\hline & $100-120$ & 8 & 1.42 & 1.51 & 1.42 & 1.42 & - & - & - & - \\
\hline
\end{tabular}

layer of $A$ or $B\left(\mathrm{~kg} \mathrm{~m}^{-3}\right)$, and $T_{\mathrm{i}}$ is the thickness of the $i$-th layer of $A$ or $B(\mathrm{~m})$.

Using the experimental data for from $A$ and $B$ and the known layer number of $n$ in the Inequality $(I)$, we can calculate $k$ (the last layer number of $B$ ). Then, we can obtain the last layer to a standardized reference depth of $B$ $\left(T_{\mathrm{Bk}}^{\prime}\right)$ using the following equations (eqn. 2 , eqn. 3):

$$
\begin{gathered}
\sum_{i=1}^{n} \rho_{A i} \cdot T_{A i}=\left(\sum_{i=1}^{k-1} \rho_{B i} \cdot T_{B i}\right)+\rho_{B k} \cdot T_{B k}^{\prime} \\
T_{B k}^{\prime}=\frac{\left(\sum_{i=1}^{n} \rho_{A i} \cdot T_{A i}\right)-\left(\sum_{i=1}^{k-1} \rho_{B i} \cdot T_{B i}\right)}{\rho_{B k}}
\end{gathered}
$$

According to results from the literature (Kern 1994, Batjes 2000, Lettens et al. 2004, Meersmans et al. 2008), the thickness of the last layer to the reference depth $(D r=1 \mathrm{~m})$ of $A$ can be calculated as follows (eqn. 4):

$$
T_{n}=D_{r}-\sum_{i=1}^{n-1} T_{i}
$$

where $T_{\mathrm{n}}$ is the thickness of the last ( $n$-th) layer to the reference depth (m).

Based on the same principle as eqn. 4, the thickness of the last layer to a standardized reference depth $\left(D_{\mathrm{SR}}\right)$ of $B$ can be calculated as follows (eqn. 5):

$$
T_{B k}^{\prime}=D_{S R}-\sum_{i=1}^{k-1} T_{B i}
$$

From eqn. 5, we can obtain the standardized reference depth $\left(D_{\mathrm{SR}}\right.$, the true depth of the disturbed reference depth - eqn. 6).

$$
D_{S R}=\sum_{i=1}^{k-1} T_{B i}+T_{B k}^{\prime}
$$

If the $T_{\mathrm{i}}$ from the field sampling was the same in the profiles of $A$ and $B$, with the calculated $k$, we can deduce that:

1. If $k>n$, then $D_{\mathrm{SR}}>D_{\mathrm{r}}$, suggesting that the soil structure of $B$ became looser than that of $A$.

2. If $k<n$, then $D_{\mathrm{SR}}<D_{\mathrm{r}}$, suggesting that the soil structure of $B$ became tighter than that 
Tab. 3 - Calculation of the last layer number $(k)$, thickness of the last layer $\left(T^{\prime}{ }_{k}\right)$ and standard reference depth $\left(D_{\mathrm{SR}}\right)$ for the different land uses considered in this study.

\begin{tabular}{llcccc}
\hline \multirow{2}{*}{ Layer } & Replicate & \multicolumn{5}{c}{ Land uses } \\
\cline { 2 - 6 } & profiles & PRF & FL & NSF & RP \\
\hline Last layer $(k)$ & No.1 & 7 & 7 & 8 & 7 \\
& No.2 & 7 & 7 & 8 & 7 \\
& No.3 & 7 & 7 & 8 & 7 \\
\hline$T^{\prime} k(\mathrm{~cm})$ & No.1 & 20 & 6.13 & 7.1 & 13.33 \\
& No.2 & 20 & 8.88 & 11.84 & 16.83 \\
& No.3 & 20 & 8.47 & 10 & 15.23 \\
\hline$D_{\text {SR }}(\mathrm{cm})$ & No.1 & 100 & 86.13 & 107.1 & 93.33 \\
& No.2 & 100 & 88.88 & 111.84 & 96.83 \\
& No.3 & 100 & 88.47 & 110 & 95.23 \\
\hline
\end{tabular}

Fig. 2 - Soil standard reference depth $\left(D_{\mathrm{SR}}\right)$ for four land uses in Xishuangbanna, according to soil reference depth $(100 \mathrm{~cm})$ and soil bulk density, obtained using the eqn. 6

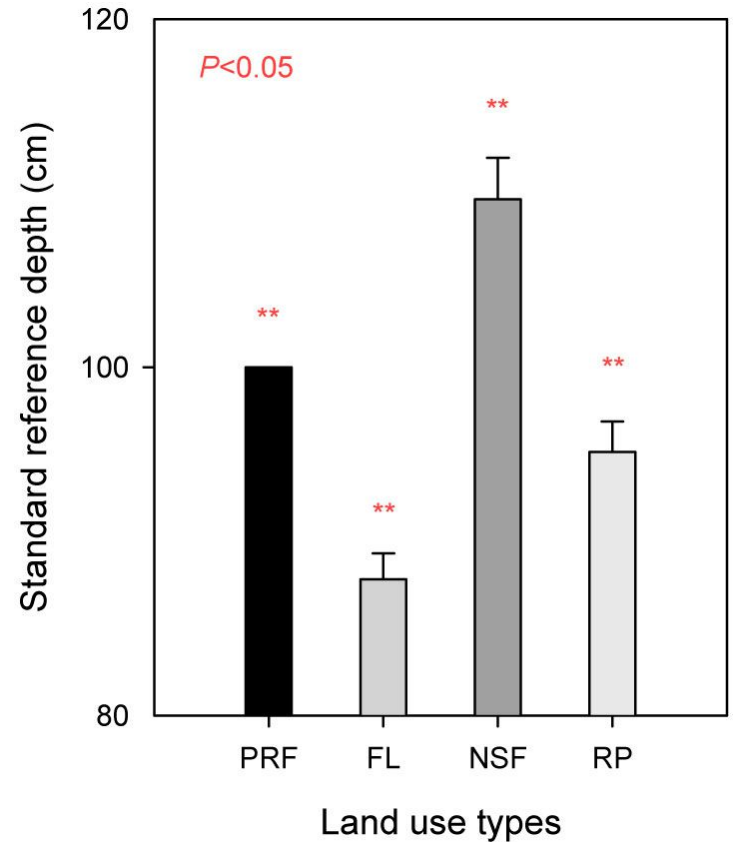

Fig. 3 - Soil organic carbon storage for four land uses in Xishuangbanna, primary rain forest (PRF) was calculated using the eqn. 8 for it was the reference land use type, the other land use types, fallow land (FL), natural secondary forest (NSF) and rubber plantation (RP) were calculated using the eqn. 9

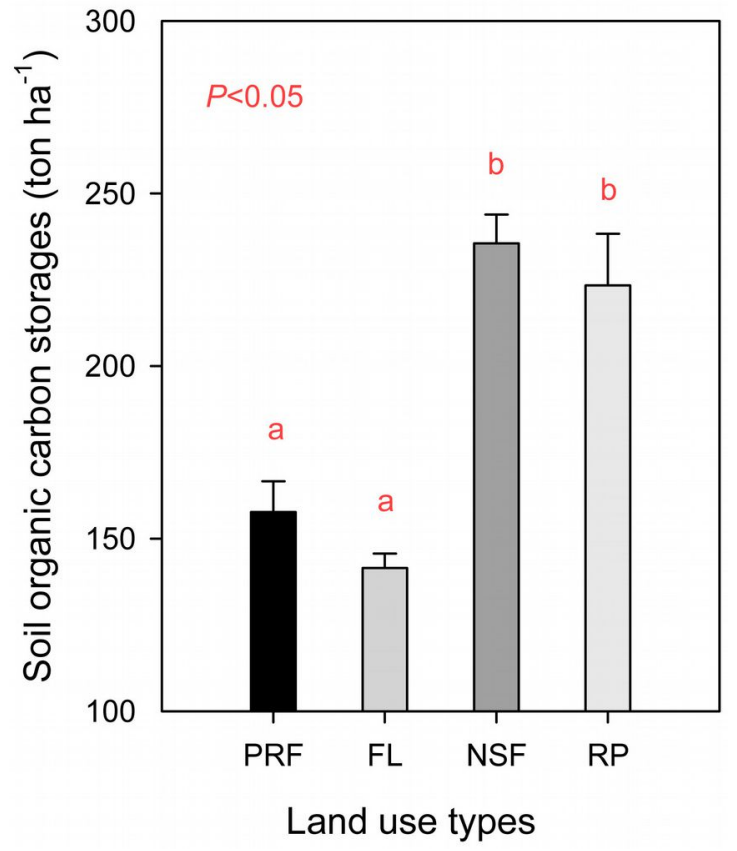

of $A$.

3. If $k=n$, then $D_{\mathrm{SR}}=D_{\mathrm{r}}$, suggesting that the soil structure of $B$ did not change from that of $A$.

Each layer's SOC density can be calculated using the following relationship based on previous research (Kern 1994, Batjes 2000, Lettens et al. 2004, Meersmans et al. 2008 eqn. 7):

$$
\operatorname{SOC}_{D i}=\rho_{i} \cdot S O C_{i} \cdot K
$$

where $S O C_{\mathrm{Di}}$ is the SOC density of the $i$-th layer $\left(\mathrm{kg} \mathrm{m}^{-3}\right), S O C_{\mathrm{i}}$ is the SOC content of the $i$-th layer $\left(\mathrm{g} \mathrm{g} \mathrm{g}^{-1}\right)$, and $K$ is the correction factor for the carbon analysis method.

The per unit surface area SOC mass of profile $A$ can be calculated using the eqn. 8 . The soil carbon storage of $A$ is the sum of the SOC mass densities of every layer in the reference depth of $D_{\mathrm{r}}$ (i.e., SOC density of the $i$-th layer multiplied by the thickness of the layer, $T_{\mathrm{i}}$ - eqn. 8 ):

$$
S O C_{m}=\sum_{i=1}^{n} S_{D C} \cdot T_{i}
$$

Based on the same principle as eqn. 7 , the per unit surface area SOC mass for the profile of $B$ can be calculated using the eqn. 8 as the sum of the SOC mass densities of each layer over the depth of $\left(D_{\mathrm{SR}}\right)$ as the soil carbon storage of B at a depth of $D_{\mathrm{r}}$ (eqn. 9):

$$
S O C_{m}=\sum_{i=1}^{k-1} S O C_{D i} \cdot T_{i}+S O C_{D k} \cdot T_{k}
$$

\section{Statistical analysis}

In all of the analyses, site types were used as replicate profiles $(\mathrm{N}=3)$. Where sub-samples were collected from each profile at every site type, the mean of the sub-samples was used. An "independent samples $t$-test" was adopted to compare the means of the standard reference depths and soil organic carbon storage under different land use types with the two different calculation methods. All of the statistical analyses were conducted using the SPSS ${ }^{\circledR} 13.0$ statistical package.

\section{Results}

\section{Standard reference depth $\left(D_{S R}\right)$}

We considered the primary rain forest as the reference land use type. According to related studies (Kern 1994, Batjes 2000, Meersmans et al. 2008), a reference depth of 1 $\mathrm{m}$ was selected. The last layer number $(k)$ of the other land uses was calculated using the inequality $(I)$ from Tab. 3. The last layer numbers for fallow land and rubber plantations were 7 , which were the same as the reference primary rain forest, but the last layer number of the natural secondary forest was 8.

Using eqn. 3, we obtained the last layer thickness $\left(T_{\mathrm{k}}^{\prime}\right)$ for fallow land, natural se- 
condary forest and rubber plantations: $7.83 \pm$ $0.86,9.65 \pm 1.38$ and $15.13 \pm 1.01 \mathrm{~cm}$, respectively (Tab. 3). Using eqn. 6 , we obtained the average standard reference depths $\left(D_{\mathrm{SR}}\right)$ of $87.83,109.65$ and $95.13 \mathrm{~cm}$, respectively (Fig. 2). Compared to the soil for the reference primary rain forest, soil density on fallow land and rubber plantations was significantly higher $(13.9 \%, P=0.005$ and $5.1 \%, P=0.009$, respectively), while the soil density for the natural secondary forest was significantly lower $(8.8 \%, P=0.002)$.

\section{Soil organic carbon storage for different land uses}

The soil organic carbon storage data for different land uses are displayed in Fig. 2. We omitted the correction factor $(K)$ from the storage calculation. Using our modified calculation method, the soil organic carbon storage densities were $157.8 \pm 8.9,141.5 \pm$ $4.1,235.5 \pm 8.4$ and $223.4 \pm 15.0$ ton $\mathrm{ha}^{-1}$ for primary rain forest, fallow land, natural secondary forest and rubber plantations, respectively (Fig. 3). When the land use type was transformed from primary rain forest to fallow land, the soil organic carbon storage decreased by approximately $10.3 \%$, but this decrease was not significant $(P=0.172)$. The soil organic carbon storage increased significantly by approximately $49.3 \%$ with the conversion to natural secondary forest $(P=0.003)$ and by $41.6 \%$ with the conversion to rubber plantation ( $P=0.020$ - Fig. 3$)$.

\section{Comparison of the two calculation methods}

The soil standard reference depth $\left(D_{\mathrm{SR}}\right)$ that was used in the carbon storage calculation is provided in Fig. 4, and the soil organic carbon storage values from the two calculation methods are compared in Fig. 5. Values for the primary rain forest were same for the two methods as the primary rain forest was the reference land use type, and the reference depth $\left(D_{\mathrm{r}}\right)$ was the same as the standard reference depth $\left(D_{\mathrm{r}}=D_{\mathrm{SR}}=100 \mathrm{~cm}\right)$. The results for the other land uses varied between the calculation methods. For fallow land, the value was $153.9 \pm 4.0$ ton $\mathrm{ha}^{-1}$ using the reference depth $\left(D_{\mathrm{r}}=100 \mathrm{~cm}\right)$ from the current method and $141.5 \pm 4.1$ ton ha $^{-1}$ using the modified method with the standardized reference depth $\left(D_{\mathrm{SR}}=87.8 \mathrm{~cm}\right)$. The current method overestimated the carbon storage by 12.4 ton $\mathrm{ha}^{-1}$, which was $8.8 \%$ more than the actual storage. For rubber plantations, the storage value was $231.4 \pm 14.1$ ton ha ${ }^{-1}$ with the reference depth $\left(D_{\mathrm{r}}=100 \mathrm{~cm}\right)$ from the current method and $223.4 \pm 15.0$ ton $\mathrm{ha}^{-1}$ with the standardized reference depth $\left(D_{\mathrm{SR}}=\right.$ $95.1 \mathrm{~cm}$ ) from the modified method. The soil organic carbon storage was overestimated by 8.1 ton $\mathrm{ha}^{-1}(3.6 \%)$. The natural secondary forest was different. The current method underestimated the carbon storage by 15.1 ton

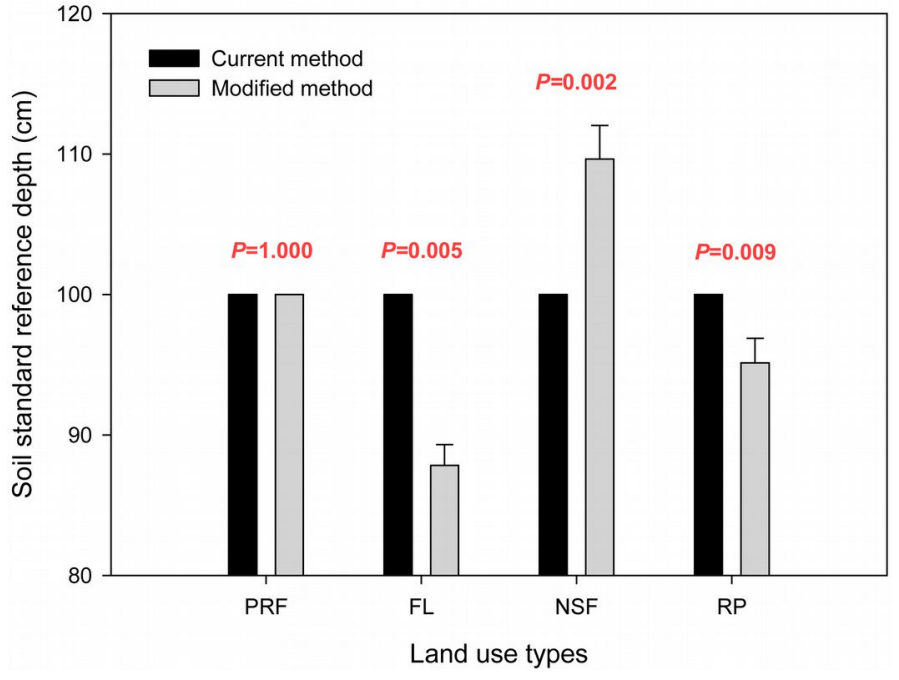

Fig. 4 - Comparison of soil standard reference depth $\left(D_{\mathrm{SR}}\right)$ values obtained with the two calculation methods considered (black bars: current depth method; gray bars: modified depth method). (P): probability from the $t$ test for the equality of means within the same land use type.

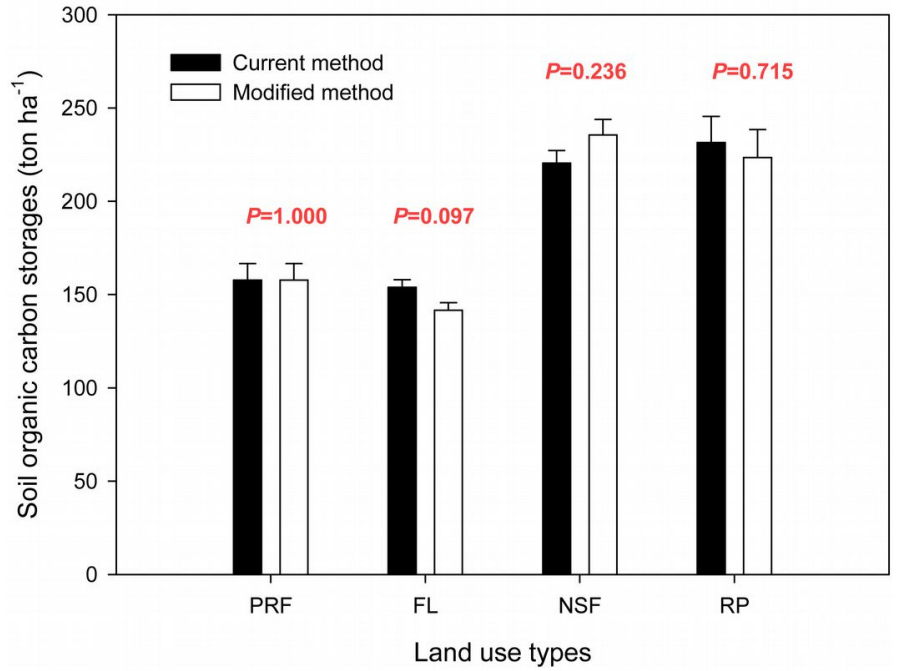

Fig. 5 - Comparison of the soil organic carbon storage values obtained with the two calculation methods considered (black bars: current SOC method; gray bars: modified SOC method). (P): probability from the $t$ test for the equality of means within the same land use type.

Tab. 4 - Results of the independent samples $t$-tests applied for the equality of soil organic carbon storage means obtained with the two calculation methods for the different land uses considered.

\begin{tabular}{|c|c|c|c|c|c|c|c|}
\hline \multirow{2}{*}{$\begin{array}{l}\text { Calculation } \\
\text { method }\end{array}$} & \multirow{2}{*}{$\begin{array}{l}\text { Land } \\
\text { uses (I) }\end{array}$} & \multirow{2}{*}{$\begin{array}{l}\text { Land } \\
\text { uses }(J)\end{array}$} & \multicolumn{2}{|c|}{$\begin{array}{c}\text { Levene's Test for } \\
\text { Equality of } \\
\text { Variances }\end{array}$} & \multicolumn{3}{|c|}{$\begin{array}{c}t \text {-test for } \\
\text { Equality of Means }\end{array}$} \\
\hline & & & $\mathbf{F}$ & Prob & $t$ & df & $\begin{array}{c}\text { Prob } \\
\text { (2-tailed) }\end{array}$ \\
\hline \multirow{6}{*}{$\begin{array}{l}\text { Current } \\
\text { method }\end{array}$} & PRF & FL & 1.259 & 0.325 & 0.393 & 4 & 0.714 \\
\hline & & NSF & 0.103 & 0.764 & -5.612 & 4 & 0.005 \\
\hline & & RP & 1.205 & 0.334 & -4.429 & 4 & 0.011 \\
\hline & FL & NSF & 1.73 & 0.259 & -8.415 & 4 & 0.001 \\
\hline & & RP & 5.611 & 0.077 & -5.291 & 4 & 0.006 \\
\hline & NSF & RP & 2.614 & 0.181 & -0.705 & 4 & 0.52 \\
\hline \multirow{6}{*}{$\begin{array}{l}\text { Modified } \\
\text { method }\end{array}$} & PRF & FL & 1.172 & 0.34 & 1.659 & 4 & 0.172 \\
\hline & & NSF & 0 & 0.985 & -6.363 & 4 & 0.003 \\
\hline & & $\mathrm{RP}$ & 1.771 & 0.254 & -3.767 & 4 & 0.02 \\
\hline & FL & NSF & 1.97 & 0.233 & -10.035 & 4 & 0.001 \\
\hline & & $\mathrm{RP}$ & 7.293 & 0.054 & -5.262 & 4 & 0.006 \\
\hline & NSF & $\mathrm{RP}$ & 2.12 & 0.219 & 0.706 & 4 & 0.519 \\
\hline
\end{tabular}


ha $^{-1}$, which was $6.4 \%$ less than the actual storage $\left(220.4 \pm 6.8\right.$ ton ha ${ }^{-1}$ at $D_{\mathrm{r}}=100 \mathrm{~cm}$ vs. $235.5 \pm 8.4$ ton $\mathrm{ha}^{-1}$ at $D_{\mathrm{SR}}=109.7 \mathrm{~cm}$ ). Although the standard reference depth using the modified method was significantly different from the reference depth using the current method under the same land use type $(P=0.005$ in $\mathrm{FL}, P=0.002$ in NSF, $P=0.009$ in RP - Fig. 4), there were no significant differences in the soil carbon storage between the two calculation methods for the same land use type $(P=1.000$ in PRF, $P=0.097$ in FL, $P=0.236$ in NSF, $P=0.715$ in RP - Fig. $5)$.

\section{Discussion}

\section{Influence of land use changes}

Long-term experimental studies have confirmed that soil organic carbon is highly sensitive to land use change from native ecosystems, such as forest or grassland, to agricultural systems, resulting in the loss of organic carbon (Paul et al. 1997). There was a $20-50 \%$ loss of top soil original carbon in the tropics and sub-tropics due to forest clearing and conversion to agricultural land (Somebroek et al. 1993). Soil organic carbon storage decreased by $30-50 \%$ due to land use changes from natural to agricultural ecosystems in the Midwestern USA (Lal 2002).

Deforestation and subsequent agricultural land abandonment in tropical and subtropical areas can result in a loss of soil carbon (Zheng et al. 2005). Tropical soils are believed to be more vulnerable to improper land management practices than soils in the temperate zone (Zhang et al. 2007b). In our study, there was no significant difference in soil carbon storage between primary rain forest and fallow land sites, although a decrease was observed $(157.8 \pm 8.9$ and $141.5 \pm 4.1$ ton ha $^{-1}, P=0.172$ - Fig. 5 and Tab. 4). Some authors have suggested that no significant loss in organic carbon due to land fallowing may occur because of the continuous production of grass vegetation that increases the soil organic matter through its fine roots (Brown \& Lugo 1990, Paul et al. 2010). The Dai's traditional slash and burn cultivation may be another important factor for soil organic carbon input through the burning of wood and litter fall during land clearing.

An increasing number of field studies have demonstrated that soil carbon concentrations at tree plantations are significantly lower than those of natural forests (Liao et al. 2012, Freier et al. 2010, Nsabimana et al. 2008, Chen et al. 2005, Lemenih et al. 2004, Solomon et al. 2002). Rubber farming has caused declining soil $\mathrm{pH}$ and organic matter content in Ferralsols (Zhang \& Zhang 2005). Soil organic carbon on rubber plantations was only $60 \%$ of that in old-growth forests after 40 years in Ghana (Duah-Yentumi et al. 1998). In a 20 years old rubber plantation in
Xishuangbanna (China), carbon in the top $10 \mathrm{~cm}$ of soil decreased from $30 \mathrm{~g} \mathrm{~kg}^{-1}$ in the native forest to $23 \mathrm{~g} \mathrm{~kg}^{-1}$ (Zhang et al. 2007c). In our study, however, the monoculture rubber plantation was similar to the natural secondary forest in its carbon storage, with the standardized soil reference depth of $1 \mathrm{~m}\left(223.4 \pm 15.0\right.$ and $235.5 \pm 8.4$ ton $\mathrm{ha}^{-1}$, $P=0.519$ - Fig. 5 and Tab. 4) over the same time period (30 years). Our results are similar to those of Marín-Spiotta \& Sharma (2012). In Xishuangbanna, the soil carbon storage at rubber plantations was $57.8 \%$ higher than that of fallow land $(P=0.006)$, and $66.4 \%$ higher in the natural secondary forest $(P=0.001$ - Fig. 5 and Tab. 4). This finding indicates that, in addition to natural reforestation, rubber plantations are another option that favors soil carbon sequestration when transforming fallow lands within the scope of the appropriate average air temperature and altitude $\left(>20{ }^{\circ} \mathrm{C},<750 \mathrm{~m}\right)$ under "the Grain for Green Project of China" in the tropical mountainous regions of southwest China. With increasing altitude of more than $750 \mathrm{~m}$ above the sea level, not only does the latex production of the rubber tree decline greatly, but its soil carbon sequestration ability also fell sharply (De Blécourt et al. 2013).

The increase in soil carbon storage for rubber plantations and natural secondary forest, compared to primary rain forest $(41.6 \%$, and $49.3 \%$ higher, $P=0.020, P=0.001$, respectively - Fig. 5 and Tab. 4), was inconsistent with other reports from tropical regions (Marín-Spiotta \& Sharma 2012). Our results for soil carbon sequestration at rubber plantations are similar to those for natural secondary forest. The soil at rubber plantations acts as a carbon sink in this region. This inconsistency may have stemmed from the influence of the land use change history and management in different study regions (Liao et al. 2012). For example, tree plantations in other regions may tend to be established on lands where soil $\mathrm{C}$ and nutrient stocks have already been depleted through agricultural or other human activities (Lugo \& Brown 1993), but there is a continuous and elaborated trend in rubber plantations for harvesting more latex in Xishuangbanna (Tab. 1). The selection of tree species may be another important factor (Marín-Spiotta \& Sharma 2012). Laganière et al. (2010) noted that the similarities and differences between tree plantations, natural secondary forests and reference primary forests had a certain relationship with the climate of the study region. The rubber tree is a species with centralized defoliation that produces a large amount of litterfall, and the decomposition rate of the litterfall is low under the relatively dry and hot northern tropical climate.

Although soil at rubber plantations acts as a carbon sink in Xishuangbanna, we still can not determine whether the rubber plantation ecosystem is a carbon source or carbon sink; for this, we need to combine the characteristics of aboveground biomass and litter-fall to comprehensively evaluate its status in future studies.

\section{Difference between the two calculation methods}

Tab. 4 lists the multiple comparisons of soil organic carbon storage using the two calculation methods for the four land use types. An "independent samples t-test" was adopted to compare the means of the standard reference depths and soil organic carbon storage for different land use types with two different calculation methods.

There was no statistically significant difference between the two calculation methods for soil organic carbon storage in the northern tropical ecosystem of southwest China. For the same land use type, such as fallow land, the depths that were used in the calculation formula were significantly different between the two methods $(100 \mathrm{~cm}$ in current method and $87.83 \mathrm{~cm}$ in modified method, $P=0.005$ - Fig. 4), but there was no significant difference in the soil organic carbon storage between the two methods (153.9 ton ha $^{-1}$ using the current method vs. 141.5 ton $\mathrm{ha}^{-1}$ with the modified method, $P=0.097$ Fig. 5).

When we compared the soil organic carbon storage determined using the two calculation methods for the different land use types, the values of significance in the $t$-test were also greater than 0.05 . Similar to the comparison of the calculation results for primary rain forest and fallow land, there was no significant difference between primary rain forest and fallow land in the current or modified methods, but the $t$-test values were different (0.714 using the current method vs. 0.172 with the modified method - Tab. 4). The relationship between the primary rain forest and rubber plantations was also similar: there was a significant difference between them $(P<0.05)$ using the current and modified calculation methods, but the $t$-test values were 0.011 for the current method and 0.020 for the modified method (Tab. 4).

Although the number of replicates was somewhat low and there was no statistically significant difference between the two calculation methods for soil organic carbon storage based on just three profiles for each study site in Xishuangbanna, we concluded that our method for standardizing the reference depth can improve the calculation accuracy by approximately $4-9 \%$. This value is a low error rate for a region but a high rate for a large area, such as a country or on a global scale. Thus, the standardization of the reference depth should be an indispensable process for country or global soil carbon storage evaluations and comparisons, even during 
the periodic Kyoto carbon trading quota allocations and goal setting for reducing $\mathrm{CO}_{2}$ emissions levels. With the reference depth standardization process, we can further model the standard soil profiles for different regions by collecting soil profile data from areas with primary vegetation (with no human disturbance) and estimate soil organic carbon or other nutrient storage changes due to land use change from primary vegetation either in a specific region or at a global level.

\section{Conclusions}

To improve the accuracy of soil organic carbon storage calculations and their comparability for land use changes, we added a new concept (standardized reference depth, $\left.D_{\mathrm{SR}}\right)$ in order to modify the current calculation method. We discovered that the $D_{\mathrm{SR}}$ can effectively reduce the calculation error rate by approximately $6.3 \%$ from the current method for evaluating the influence of land use change on soil organic carbon storage in a northern tropical ecosystem in south-western China. The modified process uses the standardization of the reference depth, and is necessary in country or global soil carbon storage evolutions and comparisons. We also obtained the unexpected result that rubber plantations have similar soil carbon sequestration abilities to natural secondary forests in Xishuangbanna. Soils at rubber plantations in this region act as a carbon sink.

\section{Acknowledgements}

This study was supported by the projects of the Natural Science Foundation of China (NSFC41201298), the Strategic Priority Research Program of the Chinese Academy of Sciences (XDA05070303), and the Opening Project Fund of Key Laboratory of Rubber Biology and Genetic Resource Utilization, Ministry of Agriculture of China (RRIKLOF1407). We thank the staff members of Xishuangbanna Station for Tropical Rainforest Ecosystem Studies for their assistance in the field work and Biogeochemistry Lab of Xishuangbanna Tropical Botanical Garden, Chinese Academy of Sciences for soil analysis. We are also grateful to Dr. Chao Shang, Crop and Soil Environmental Science Department, Virginia Polytechnic Institute and State University and to Dr. Charles H. Cannon, Department of Biological Sciences, Texas Tech University, for their valuable comments and editing the English language on the manuscript.

\section{References}

Barnett TP, Adam JC, Lettenmaier DP (2005). Potential impacts of a warming climate on water availability in snow dominated regions. Nature 438: 303-309. - doi: 10.1038/nature04141

Batjes NH (1996). Total carbon and nitrogen in the soils of the world. European Journal of Soil Science 47: 151-163. - doi: 10.1111/j.1365-23 89.1996.tb01386.x

Batjes NH, Sombroek WG (1997). Possibilities for carbon sequestration in tropical and subtropical soils. Global Change Biology 3: 161-173. doi: $10.1046 / j .1365-2486.1997 .00062 . x$

Batjes NH (2000). Effects of mapped variation in soil conditions on estimates of soil carbon and nitrogen stocks for South America. Geoderma 97: 135-144. - doi: 10.1016/S0016-7061(00)000 31-8

Brown S, Lugo AE (1990). Tropical secondary forests. Journal of Tropical Ecology 6: 1-32. doi: 10.1017/S0266467400003989

De Blécourt M, Brumme R, Xu J, Corre MD, Veldkamp E (2013). Soil carbon stocks decrease following conversion of secondary forests to rubber (Hevea brasiliensis) plantations. PLoS ONE 8(7): e69357. - doi: 10.1371/journal.pone.0069 357

Cao M, Zhang JH, Feng ZL, Deng JW, Deng XB (1996). Tree species composition of a seasonal rain forest in Xishuangbanna, Southwest China. Tropical Ecology 37: 183-192. [online] URL: http://cat.inist.fr/?aModele $=$ afficheN\&cpsidt $=10$ 145848

Chen GS, Yang YS, Xie JS, Guo JF, Gao R, Qian W (2005). Conversion of a natural broad-leafed evergreen forest into pure plantation forests in a subtropical area: effects on carbon storage. Annals of Forest Science 62 (7): 659-668. - doi: 10.1051/forest:2005073

Duah-Yentumi S, Rønn R, Christensen S (1998). Nutrients limiting microbial growth in a tropical forest soil of Ghana under different management. Applied Soil Ecology 8: 19-24. - doi: 10.1016/S 0929-1393(97)00070-X

Ellert BH, Bettany JR (1995). Calculation of organic matter and nutrients stored in soils under contrasting management regimes. Canadian Journal of Soil Science 75: 529-538. - doi: 10.4141/ cjss95-075

FAO (2005). Global forest resources assessment 2005. FAO Forestry Paper 147, FAO, Rome. [online] URL: http://www.fao.org/forestry/site/ fra2005/en/

FAO (2010). Global forest resources assessment 2010. FAO Forestry Paper 163, FAO, Rome. [online] URL: http://www.fao.org/forestry/site/ fra2010/en

Freier KP, Glaser B, Zech W (2010). Mathematical modeling of soil carbon turnover in natural Podocarpus forest and Eucalyptus plantation in Ethiopia using compound specific $\delta^{13} \mathrm{C}$ analysis. Global Change Biology 16: 1487-1502. - doi: 10.1111/j.1365-2486.2009.02096.x

John B, Yamashita T, Ludwig B, Flessa H (2005). Storage of organic carbon in aggregate and density fractions of silty soils under different types of land use. Geoderma 128: 63-79. - doi: 10.1016/j.geoderma.2004.12.013

Kern JS (1994). Spatial patterns of soil organic carbon in the contiguous United States. Soil Science Society of America Journal 58: 439-455. doi: 10.2136/sssaj1994.03615995005800020029 $\mathrm{x}$

Laganière J, Angers DA, Paré D (2010). Carbon accumulation in agricultural soils after afforestation: a meta-analysis. Global Change Biology 16 : 439-453. - doi: 10.1111/j.1365-2486.2009.019 30.x

Lal R (2002). Soil carbon dynamics in cropland and rangeland. Environmental Pollution 116: 353-362. - doi: 10.1016/S0269-7491(01)002111

Lemenih M, Olsson M, Karltun E (2004). Comparison of soil attributes under Cupressus lusitanica and Eucalyptus saligna established on abandoned farmlands with continuously cropped farmlands and natural forest in Ethiopia. Forest Ecology and Management 195: 57-67. - doi: 10.1016/j.foreco.2004.02.055

Lettens S, Van Orshoven J, Van Wesemael B, Muys B (2004). Soil organic and inorganic carbon contents of landscape units in Belgium derived using data from 1950 to 1970 . Soil Use Management 20: 40-47. - doi: 10.1079/SUM20 03221

Li HM, Aide TM, Ma YX, Liu WJ, Cao M (2007). Demanding for rubber is causing the loss of high diversity rain forest in SW China. Biodiversity Conservation 16: 1731-1745. - doi: 10.10 07/s10531-006-9052-7

Li Y, Deng X, Cao M, Lei Y, Xia Y (2013). Soil restoration potential with corridor replanting engineering in the monoculture rubber plantations of Southwest China. Ecological Engineering 51: 169-177. - doi: 10.1016/j.ecoleng.2012.12.081

Liao CZ, Luo YQ, Fang CM, Chen JK, Li B (2012). The effects of plantation practice on soil properties based on the comparison between natural and planted forests: a meta-analysis. Global Ecology and Biogeography 21: 318-327. - doi: 10.1111/j.1466-8238.2011.00690.x

Liu GS, Jiang NH, Zhang LD, Liu ZL (1996). Soil physical and chemical analysis and description of soil profiles. Standards Press of China, Beijing, China, pp. 5-6, 31-32. [in Chinese]

Liu WJ, Zhang YP, Li HM, Meng FR, Liu YH, Wang CM (2005). Fog and rainwater chemistry in the tropical seasonal rain forest of Xishuangbanna, Southwest China. Water, Air, and Soil Pollution 167: 295-309. - doi: 10.1007/s11270005-0080-9

Lugo AE, Brown S (1993). Management of tropical soils as sinks or sources of atmospheric carbon. Plant and Soil 149 (1): 27-41. - doi: 10.10 07/BF00010760

Marín-Spiotta E, Sharma S (2012). Carbon storage in successional and plantation forest soils: a tropical analysis. Global Ecology and Biogeography - doi: 10.1111/j.1466-8238.2012.00788.x Meersmans J, De Ridder F, Canters F, De Baets S, Van Molle M (2008). A multiple regression approach to assess the spatial distribution of Soil Organic Carbon (SOC) at the regional scale (Flanders, Belgium). Geoderma 143: 1-13. - doi: 10.1016/j.geoderma.2007.08.025

Nelson DM, Sommer LE (1975). A rapid and accurate method for estimating organic carbon in soil. Proceedings of the Indiana Academic Science 84: 456-462.

Nsabimana D, Klemedtson L, Kaplin BA, Wallin 
G (2008). Soil carbon and nutrient accumulation under forest plantations in southern Rwanda. African Journal of Environmental Science and Technology 2: 142-149. [online] URL: http:// www.researchgate.net/publication/228461641_S oil_carbon_and_nutrient_accumulation_under_f orest plantations_in_southern_Rwanda/file/e $0 \bar{b} 4$ 951d174b6e4974.pdf

Paul EA, Paustian K, Elliott ET, Cole CV (1997). Soil organic matter in temperate agro ecosystems. CRC Press, New York, USA, pp. 15-49, 343-351.

Paul M, Catterall CP, Pollard PC, Kanowski J (2010). Recovery of soil properties and functions in different rain forest restoration pathways. Forest Ecology and Management 259: 2083 2092. - doi: 10.1016/j.foreco.2010.02.019

Post WM, Kwon KC (2000). Soil carbon sequestration and land-use change: processes and potential. Global Change Biology 6: 317-327. - doi 10.1046/j.1365-2486.2000.00308.x

Schumacher BA (2002). Methods for the determination of the total organic carbon (TOC) in soils and sediments. EPA, Washington, DC, USA, pp. 23. [online] URL: http://epa.gov/nerlesd1/cmb/research/papers/bs116.pdf

Stocker TF, Qin D, Plattner G-K, Tignor MMB, Allen SK, Boschung J, Nauels A, Xia Y, Bex V, Midgley PM, Working Group I Technical Support Unit (2013). Climate change 2013, the physical science basis, contribution of Working Group I to the fourth assessment report of the intergovernmental panel on climate change, summary for policymakers. [online] URL: http:// www.climatechange2013.org

Sleutel S, De Neve S, Hofman G, Boeckx P, Be- heydt D, Van Cleemput O, Mestdagh I, Lootens P, Carlier L, Van Camp N, Verbeeck H, Vande Walle I, Samson R, Lust N, Lemeurb R (2003). Carbon stock changes and carbon sequestration potential of Flemish cropland soils. Global Change Biology 9: 1193-1203. - doi: 10.1046/j.13652486.2003.00651.x

Solomon D, Lehmann J, Mamo T, Fritzsche F, Zech W (2002). Phosphorus forms and dynamics as influenced by land use changes in sub-humid Ethiopian highlands. Geoderma 105: 21-48. doi: 10.1016/S0016-7061(01)00090-8

Somebroek W, Nachtergaele F, Hebel A (1993). Amounts, dynamics and sequestering of carbon in tropical and subtropical soils. Ambio 22: 417426.

Van Dijk AIJ, Keenan RJ (2007). Planted forests and water in perspective. Forest Ecology and Management 251: 1-9. - doi: 10.1016/j.foreco.20 07.06.010

Veldkamp E (1994). Organic carbon turnover in three tropical soils under pasture after deforestation. Soil Science Society of America Journal 58: 175-180. - doi: 10.2136/sssaj1994.03615995005 $800010025 \mathrm{x}$

Wilson B, Puri G (2001). A comparison of pinewood and moorland soils in the Abernethy Forest Reserve, Scotland. Global Ecology and Biogeography 10: 291-303. - doi: 10.1046/j.1466-822 X.2001.00226.X

Xu J, Grumbine RE, Beckschäfer P (2014). Landscape transformation through the use of ecological and socioeconomic indicators in Xishuangbanna, Southwest China, Mekong Region. Ecological Indicators 36: 749-756. - doi: 10.1016/j. ecolind.2012.08.023
Yang XM, Wander MM (1999). Tillage effects on soil organic carbon distribution and storage in a silt loam soil in Illinois. Soil and Tillage Research 52: 1-9. - doi: 10.1016/S0167-1987(99)0005 1-3

Zhang H, Zhang GL (2005). Landscape-scale soil quality change under different farming systems of a tropical farm in Hainan, China. Soil Use and Management 21: 58-64. - doi: 10.1079/SUM200 5293

Zhang HB, Luo YM, Wong MH, Zhao QG, Zhang GL (2007a). Soil organic carbon storage and changes with reduction in agricultural activities in Hong Kong. Geoderma 139: 412-419. - doi: 10.1016/j.geoderma.2007.03.003

Zhang H, Zhang GL, Zhao YG, Zhao WJ, Qi ZP (2007b). Chemical degradation of a Ferralsol (Oxisol) under intensive rubber (Hevea brasiliensis) farming in tropical China. Soil and Tillage Research 93: 109-116. - doi: 10.1016/j.still.20 06.03.013

Zhang M, Fu XH, Feng WT, Zou XM (2007c). Soil organic carbon in pure rubber and tea-rubber plantations in southwestern. Tropical Ecology 48: 1-7. [online] URL: http://www.tropecol.com/pdf/open/PDF_48_2/07MinZhang.pdf

Zheng H, Ouyang ZY, Wang XK, Miao H, Zhao TQ, Peng TB (2005). How different reforestation approaches affect red soil properties in southern China. Land Degradation and Development 16: 387-396. - doi: 10.1002/ldr.650

Zhou ZY, Liu J (2004). Xishuangbanna won the world's first yield production of rubber for 9 consecutive years. Web site. [in Chinese] [online] URL: http://news.xinhuanet.com/fortune/ 2004-08/31/content_1929540.htm 